\title{
Identyfikacja warunków koniecznych sukcesu serwicyzacji przedsiębiorstw produkcyjnych
}

\author{
Dr inż. Mirosław Matusek iD \\ Politechnika Śląska \\ Wydział Organizacji i Zarządzania \\ Katedra Zarządzania i Logistyki
}

\section{Wprowadzenie}

W ostatnim dziesięcioleciu przedsiębiorstwa produkcyjne doświadczały wielu transformacji, które radykalnie zmieniły koncepcje budowania przewagi konkurencyjnej, relacji z klientami, dostawcami czy sposobów rozwoju, wytwarzania i dostarczania oferty produktowej ${ }^{1}$. Obecnie szczególnych wyzwań, które stoją przed przedsiębiorstwami produkcyjnymi, upatruje się w dwóch obserwowanych makrotrendach - zjawisku serwicyzacji oraz inicjatywie Przemysłu 4.0.

Serwicyzacja to zjawisko (proces) obserwowane na poziomie gospodarek narodowych oraz na poziomie samych przedsiębiorstw, których oferta produktowa w coraz większym stopniu powiększa się o komponent usług 2 . Inni autorzy definiują zjawisko serwicyzacji jako innowacyjny sposób organizacji zdolności i procesów w celu lepszego kreowania wspólnej (klienta i dostawcy/ów) wartości poprzez przejście ze sprzedaży produktów w kierunku dostarczania zintegrowanych rozwiązań złożonych z produktów, usług i wiedzy3. Taka transformacja jest zakorzeniona w architekturze wartości oferowanych klientom rozwiązań, złożonej z mechanizmów tworzenia wartości, jej dostarczania, przechwytywania oraz z ich komplementarności ${ }^{4}$. Przemysł 4.0 z kolei uważany jest za nowy scenariusz rozwoju

1 M. Gersch, C. Goeke, Industry transformation - conceptual considerations from an evolutionary perspective, „Journal of Business Market Management” 2007, vol. 1, s. 151-182.

2 I. Lichniak, Ku gospodarce ustug, [w:] L. Lichniak (red.), Serwicyzacja polskiej gospodarki, Oficyna Wydawnicza SGH - Szkoła Główna Handlowa w Warszawie, Warszawa 2010, s. 11.

3 C. Kowalkowski, H. Gebauer, R. Oliva, Service growth in product firms: past, present, and future, „Industrial Marketing Management” 2017, vol. 60, s. 82-88; V. Martinez i wsp., Exploring the journey to services, „International Journal of Production Economics” 2017, vol. 192, s. 66-80.

4 D.J. Teece, Business models, business strategy and innovation, „Long Range Planning” 2010, vol. 43(2), s. 172-194. 
przemysłu, w którym następuje konwergencja różnych nowych technologii wspieranych przez Internet rzeczy (IoT) 5 .

Przez długi czas traktowano te kwestie jako odrębne obszary badawcze, z których pierwszy koncentruje się na wartości dla klienta, a drugi na wartości wewnętrznych procesów biznesowych ${ }^{6}$. W rzeczywistości oba trendy są ze sobą ściśle powiązane, a ich wspólną płaszczyzną są technologie cyfrowe, na których z kolei oparte są inteligentne produkty, usługi cyfrowe, masowa personalizacja oferty produktowej czy inne innowacyjne modele propozycji wartości ${ }^{7}$. Technologie i rozwiązania składające się na Przemysł 4.0, takie jak IoT, Big Data, cloud computing, analityka czy cyberbezpieczeństwo, stają się obecnie podstawą coraz bardziej złożonej i zintegrowanej oferty produktowo-usługowej ${ }^{8}$. Rozwiązania produktowo-usługowe (RPU) są różnie definiowane ${ }^{9}$. W rozdziale przyjęto, że RPU to zindywidualizowana oferta odpowiadająca na (złożone) potrzeby usługobiorców (klientów), która jest projektowana i dostarczana interaktywnie do usługobiorcy i której komponenty oferują synergiczną wartość dodaną poprzez połączenie produktów i/lub usług, tak aby jej oferowana wartość była czymś więcej niż sumą oferowanej wartości jej indywidualnych komponentów. Rozwiązania produktowo-usługowe integrują takie komponenty jak produkt, usługa i wiedza w unikalne kombinacje, w celu realizacji wymagań i potrzeb klientów. W skrajnych przypadkach nakłady poniesione przez dostawcę są rekompensowane przez usługobiorcę na podstawie wartości w użyciu (value in use).

Rozwój i dostarczanie usług czy rozwiązań produktowo-usługowych to bardziej złożone zadania niż wytwarzanie produktów, chociaż jako takie mogą nie być w ten sposób postrzegane (przynajmniej początkowo) przez menedżerów firm produkcyjnych. Alghisi i Saccani ${ }^{10}$ stwierdzili, że rozwój zaawansowanych usług bez prawidłowego dostosowania wewnętrznych komponentów organizacji (np. orientacja usługowa strategii i portfolio oferty produktowej zorientowanej na usługi) do aspektów zewnętrznych (klienci i inni uczestnicy sieć dostaw usług) może okazać się

5 G. Reischauer, Industry 4.0 as policy-driven discourse to institutionalize innovation systems in manufacturing, „Technological Forecasting and Social Change” 2018, vol. 132, s. 26-33.

6 W. Coreynen, P. Matthyssens, W. Van Bockhaven, Boosting servitization through digitization: pathways and dynamic resource configurations for manufacturers, „Industrial Marketing Management" 2017, vol. 60, s. 42-53.

7 Tamże.

8 A.G. Frank, L.S. Dalenogare, N.F. Ayala, Industry 4.0 technologies: implementation patterns in manufacturing companies, „International Journal of Production Economics” 2019, vol. 210, s. 15-26.

9 Na przykład C. Kowalkowski, H. Gebauer, R. Oliva, Service growth...; L. Żabiński, Marketing produktów systemowych, Polskie Wydawnictwo Ekonomiczne, Warszawa 2012.

10 A. Alghisi, N. Saccani, Internal and external alignment in the Servitization journey - Overcoming the challenges, „Production Planning and Control” 2015, vol. 26, s. 1219-1232. 
bardzo trudny. Rozwój przedsiębiorstw produkcyjnych poprzez zwiększenie roli usług w ofercie produktowej stwarza ogromne (nowe, nieznane do tej pory przedsiębiorstwom produkcyjnym) ryzyka strategiczne, operacyjne i finansowe. Chociaż ostatnio przeprowadzane badania ilościowe ${ }^{11}$ wskazują, że usługi mogą mieć pozytywny wpływ na wyniki przedsiębiorstw produkcyjnych, to jednak - zgodnie z koncepcją dopasowania organizacyjnego ${ }^{12}$ - zależy to od czynników wewnątrz organizacji i w jej otoczeniu. W niniejszym opracowaniu skupiono się na dopasowaniu pomiędzy ofertą usługową a strukturą organizacyjną i więzami organizacyjnymi. Gremyr i współautorzy ${ }^{13}$ wskazują w swoich badaniach, że firmy produkcyjne, które zaczynają rozwijać nowy biznes skoncentrowany na usługach, doświadczają braku równowagi między strategią a praktyką czy codziennymi działaniami podejmowanymi w przedsiębiorstwie. Autorzy ${ }^{14}$ dość powszechnie są zgodni co do tego, że źródeł tego niedopasowania należy w pierwszej kolejności upatrywać w niezgodności pomiędzy przyjętą strategią biznesową (tutaj wyrażoną poprzez ofertę produktowo-usługową) a strukturą organizacyjną zorientowaną na usługi.

Jak wykazano w dalszych częściach rozdziału, badacze nie są zgodni co do tego, czy i przy jakich warunkach integracja lub oddzielenie działalności usługowej od działalności związanej z produktem przyczynia się do sukcesu serwicyzacji producentów. Mimo że panuje zgodność co do tego, że współpraca międzyfunkcyjna oraz międzyorganizacyjna są ważnymi aspektami integracji usług i produktów w postaci zintegrowanej oferty produktowo-usługowej, to problem dotyczący tego, czy czynniki te są niezbędnymi warunkami na tym samym poziomie, przy różnym stopniu zorientowania oferty produktowej na usługi, do tej pory nie został zbadany. Ponadto większość badań nad warunkami koniecznymi sukcesu serwicyzacji, poza nielicznymi przypadkami ${ }^{15}$, to badania o charakterze eksploracyjnym, jakościowym, na podstawie studiów przypadków ${ }^{16}$.

11 Na przykład E. Böhm, A. Eggert, C. Thiesbrummel, Service transition: A viable option for manufacturing companies with deteriorating financial performance, „Industrial Marketing Management" 2017, vol. 60, s. 101-111.

12 H. Mintzberg, Structure in fives: Designing effective organizations, Prentice-Hall, Inc., Englewood Cliffs 1993.

13 I. Gremyr i wsp., Understanding new service development and service innovation through innovation modes, „Journal of Business and Industrial Marketing” 2014, vol. 29, s. 123-131.

14 Na przykład H. Gebauer, Identifying service strategies in product manufacturing companies by exploring environment - strategy configurations, „Industrial Marketing Management” 2008, vol. 37, s. 278-291; C. Raddats i wsp., Servitization: A contemporary thematic review of four major research streams, „Industrial Marketing Management” 2019, vol. 83, s. 207-223.

15 Na przyktad M. Antioco i wsp., Organizational antecedents to and consequences of service business orientations in manufacturing companies, „Journal of the Academy of Marketing Science" 2008, vol. 36, s. 337-358. 
Stąd prezentowane wyniki badań starają się dać odpowiedź na pytanie, czy, a jeśli tak, to w jaki sposób wydzielenie jednostki organizacyjnej odpowiedzialnej za dostarczanie usług oraz więzi organizacyjne warunkują osiągane poziomy przychodów ze sprzedaży usług w zależności od rodzaju oferty usługowej przedsiębiorstw produkcyjnych.

Analizę danych przeprowadzono z wykorzystaniem narzędzia do analizy warunków koniecznych Necessary Condition Analysis (NCA) ${ }^{17}$. W kolejnej części rozdziału przedstawiono stan wiedzy na temat wpływu kryteriów strukturyzacji wewnętrznej organizacji oraz współpracy organizacyjnej w zależności od rodzaju zorientowania oferty produktowej na usługi (SSP, SSC). Następnie przedstawiono metodę badawczą, przebieg badań oraz ich wyniki. Opracowanie zakończono wnioskami ze wskazaniem przyszłych kierunków badań.

\section{Przegląd badań}

\section{Rodzaj zorientowania oferty produktowej na ustugi a strukturyzacja wewnętrzna organizacji}

W badaniach nad warunkami sukcesu serwicyzacji przedsiębiorstw produkcyjnych jednym z najczęściej wymienianych czynników jest struktura organizacyjna zorientowana na dostarczanie zintegrowanych rozwiązań produktowo-usługowych ${ }^{18}$. Struktura organizacyjna jest - obok ludzi, techniki i celów - jednym z elementów systemu organizacyjnego. Jej istota polega na odpowiednim spojeniu celów i zadań organizacji, wynikających ze strategii i technologii procesów wykonawczych, z ludźmi i sposobami oddziaływania na nich w procesie pracy ${ }^{19}$. Definiuje ona układ elementów przedsiębiorstwa i relacje zachodzące między nimi. Sposób podziału pracy na różne zadania, tj. integracja i/lub rozdział zadań i obowiązków, ma swoje odzwierciedlenie w odrębności organizacyjnej działań związanych z oferowanymi produktami i usługami. Ich odrębność reprezentuje stopień, w jakim zadania i obowiązki związane z działalnością usługową są zintegrowane w postaci

17 J. Dul, Necessary condition analysis (NCA) logic and methodology of „Necessary but Not Sufficient” causality, „Organizational Research Methods” 2016, vol. 19, s. 10-52.

18 S. Fliess, E. Lexutt, How to be successful with servitization - Guidelines for research and management, „Industrial Marketing Management” 2019, vol. 78, s. 58-75; C. Raddats i wsp., Servitization...

19 A. Zakrzewska-Bielawska, Relacje między strategiq a strukturq organizacyjna w przedsiębiorstwach sektora wysokich technologii, „Zeszyty Naukowe Politechniki Łódzkiej” 2011, nr 1095, s. 181. 
wyodrębnionej jednostki w strukturze organizacyjnej czy strategicznej jednostce biznesowej ${ }^{20}$. Przedsiębiorstwo produkcyjne, przyjmując orientację usługową, zmienia swoją ofertę produktową w kierunku wzrostu udziału usług czy zintegrowanych rozwiązań produktowo-usługowych. Tym samym wzrasta poziom zdywersyfikowania biznesów organizacji. Jak pisze Zakrzewska-Bielawska ${ }^{21}$, jest to jeden z czynników wpływających na większy stopień strukturalizacji organizacji (poprzez tworzenie dywizji, obiektów). Można zatem przypuszczać, że ze wzrostem poziomu orientacji usługowej, ze wzrostem dojrzałości serwicyzacji przedsiębiorstw produkcyjnych będą one starały się wydzielać jednostki odpowiedzialne za rozwój i dostarczanie usług od tych, które są odpowiedzialne dostawę produktów.

Rzeczywiście, część autorów ${ }^{22}$ wskazuje, że odrębność organizacyjna biznesu usług jest pozytywnie związana z orientacją usługową przedsiębiorstw produkcyjnych. Gebauer i współautorzy argumentują to tym, że przedsiębiorstwa produkcyjne, które od początku swojej działalności opierały swój model biznesu na sprzedaży produktów, jednocześnie integrując w tej samej jednostce organizacyjnej zadania związane z usługami, nie są w stanie wystarczająco skoncentrować się na usługach czy zrozumieć ich unikalnych wymagań ${ }^{23}$. Integracja zadań związanych z produktami i usługami w jednej strukturze organizacyjnej to dowód na to, że menedżerowie nie dostrzegają zasadniczych różnic między biznesem produktów i usług. Sprzyja to niskiemu poziomowi orientacji usługowej w strukturach organizacyjnych, co z kolei prowadzi do osiągania niesatysfakcjonujących wyników związanych ze sprzedażą oferty usługowej. Wydzielenie jednostki odpowiedzialnej za biznes usług wspiera orientację usługową przedsiębiorstwa i sprzyja uniknięciu zjawiska paradoksu usług24. Wyodrębnienie jednostki usługowej pozwala w pełni autonomicznie zarządzać relacjami z klientami, rozwijać ofertę usługową, ustalać jej cenę oraz wybierać sposoby dostarczania usług 25 . Wydzielenie organizacji

20 R. Oliva, H. Gebauer, J.M. Brann, Separate or integrate? Assessing the impact of separation between product and service business on service performance in product manufacturing firms, „Journal of Business-to-Business Marketing” 2012, vol. 19, s. 309-334.

21 A. Zakrzewska-Bielawska, Determinanty struktury organizacyjnej na przykładzie dużych polskich przedsiębiorstw produkcyjnych, [w:] J. Skalik (red.), Zmiana warunkiem sukcesu. Przeobrażenia systemów zarządzania przedsiębiorstw, „Prace Naukowe Akademii Ekonomicznej we Wrocławiu", Wydawnictwo Akademii Ekonomicznej we Wrocławiu, Wrocław 2007, s. 102-103.

22 Na przykład H. Gebauer, Identifying service strategies...

23 H. Gebauer i wsp., Service Orientation of Organizational Structures, „Journal of Relationship Marketing" 2009, vol. 8: 2, s. 109.

24 M. Matusek, Innowacje usług w przedsiębiorstwach produkcyjnych-jak uniknq̨ć „paradoksu usług”, „Organizacja i Kierowanie” 2016, nr 2, s. 87-103.

25 B.G. Auguste, E.P. Harmon, V. Pandit, The right service strategies for product companies, „McKinsey Quarterly” 2006, vol. 1, s. 40-51; H. Gebauer, Identifying service strategies... 
usługowej podkreśla strategiczne zaangażowanie przedsiębiorstwa produkcyjnego w działalność usługową ${ }^{26}$, ponadto - jak wykazali Oliva, Gebauer i Brann ${ }^{27}$ - niezależna jednostka usługowa w strukturze organizacyjnej pozytywnie wpływa na osiągane przez przedsiębiorstwo wyniki ze sprzedaży usług.

$\mathrm{Z}$ drugiej strony $\mathrm{Neu}^{28}$ postuluje coś zupełnie przeciwnego. Jego zdaniem stworzenie w strukturze organizacyjnej autonomicznej jednostki usługowej ogranicza rozwój działalności usługowej. W konsekwencji wydzielenie jednostki usługowej może ograniczać korzyści osiągane przez przedsiębiorstwo. Przyczynę tego tłumaczy się w marketingu zwiększeniem momentów (punktów) kontaktu z klientem, co może zaszkodzić relacjom z nim. W ten sposób wydzielenie jednostki usługowej w przedsiębiorstwie produkcyjnym może zwiększać w znaczący sposób wysiłki koordynacyjne między przedsiębiorstwem a klientami ${ }^{29}$. Rozdzielenie działalności związanej z produktami i usługami może prowadzić do wewnętrznych konfliktów. Ponadto wydzielenie działalności usługowej stwarza zagrożenie dla działalności związanej z produktami, co oznacza, że firmy napotykają wewnętrzny opór ze strony działalności związanej z produktami, a menedżerowie muszą radzić sobie z konfliktami na styku działalności usługowej i produktowej ${ }^{30}$. W kolejnych badaniach Neu i Brown ${ }^{31}$ potwierdzają, że w przypadku integracji jednostki usługowej z jednostką produktową można uzyskać efekt synergii w postaci rozwiązań produktowo-usługowych oraz poprawę transferu wiedzy w procesie rozwoju i dostarczania takich rozwiązań.

Przy takich sprzecznościach prowadzono badania nad wpływem wydzielenia autonomicznej jednostki usługowej na osiągane efekty, w zależności od zorientowania na usługi posiadanej oferty produktowej (od rodzaju usług posiadanych w ofercie produktowej). Usługi nie są jednorodne i autorzy klasyfikują je według różnych kryteriów ${ }^{32}$. Jednak klasyfikacją usług najczęściej używaną w badaniach nad serwicyzacją jest ta, która została zaproponowana przez Mathieu33. Autorka dzieli usługi na te,

26 Na przykład H. Gebauer i wsp., Service Orientation...

27 R. Oliva, H. Gebauer, J.M. Brann, Separate or integrate?...

28 W.A. Neu, Forming successful business-to-business services in goods-dominant firms, „Journal of Service Research" 2005, vol. 8, s. 3-17.

29 Z. Raja Jawwad i wsp., Organizing for servitization: examining front-and back-end design configurations, „International Journal of Operations \& Production Management” 2018, vol. 38 , issue 1, s. 249-271.

30 H. Gebauer i wsp., Service Orientation...

31 W.A. Neu, S.W. Brown, Manufacturers forming successful complex business services: Designing an organization to fit the market, „International Journal of Service Industry Management” 2008 , vol. 19, s. 232-251.

32 Więcej na przykład w: C. Raddats i wsp., Servitization...

33 V. Mathieu, Product services: from a service supporting the product to a service supporting the client, „Journal of Business and Industrial Marketing” 2001, vol. 16, s. 39-58. 
które zapewniają poprawne funkcjonowanie produktu (SSP) (związane z dostarczanym produktem, np. działania serwisowe), oraz te, które wspierają działania klienta (SSC) (np. konsulting, usługi nakierowane na poprawę procesów biznesowych czy operacyjnych u klienta). Oferta produktowa, na którą składają się usługi wspierające działania klienta, charakteryzuje się większym stopniem orientacji usługowej ${ }^{34}$. Fliess i Lexutt ${ }^{35}$ twierdzą, że im bardziej oferta produktowa zorientowana jest na usługi, tym bardziej odpowiednia jest struktura z wydzieloną jednostką usługową. Kowalkowski, Gebauer i Oliva $^{36}$, Gebauer i współautorzy ${ }^{37}$ oraz Oliva, Gebauer i Brann ${ }^{38}$ - wręcz przeciwnie - stwierdzają, że autonomiczna jednostka organizacyjna jest odpowiednia przy niskim poziomie orientacji usługowej oferty produktowej. Z kolei we wspomnianych już pracach Neua ${ }^{39}$ czy Neua i Browna ${ }^{40}$ autorzy prowadzili badania na próbie przedsiębiorstw produkcyjnych mających ofertę produktową charakteryzującą się wysokim poziomem orientacji usługowej typu SSC (w ich ofercie produktowej dominowały usługi wspierające działania klienta). Potwierdzili oni słuszność integracji jednostki organizacyjnej odpowiedzialnej za produkty z usługami.

\section{Rodzaj zorientowania oferty produktowej na usługi a więzi organizacyjne}

Struktura organizacyjna to nie tylko sposób na integrację lub podział zadań, jest ona także elementem, który determinuje współpracę wewnątrz i na zewnątrz organizacji. Stąd też problem wyodrębnienia jednostki usługowej w strukturze organizacyjnej przedsiębiorstw produkcyjnych wchodzących na drogę serwicyzacji związany jest z dyskusją nad wpływem współdziałania międzyfunkcyjnego oraz międzyorganizacyjnego na orientację usługową przedsiębiorstw ${ }^{41}$. Więzy organizacyjne to relacje współzależności mające charakter interakcji zasileń materiałowych i informacyjnych wewnątrz przedsiębiorstwa ${ }^{42}$. Podobnie definiowane są więzi międzyorganizacyjne - jako takie oddziaływania pomiędzy

34 M. Antioco i wsp., Organizational antecedents...

35 S. Fliess, E. Lexutt, How to be successful with servitization...

36 C. Kowalkowski, H. Gebauer, R. Oliva, Service growth in product firms...

37 H. Gebauer i wsp., Service Orientation...

38 R. Oliva, H. Gebauer, J.M. Brann, Separate or integrate?...

39 W.A. Neu, Forming successful...

40 W.A. Neu, S.W. Brown, Manufacturers forming successful complex business services...

41 C. Raddats i wsp., Servitization...; H. Gebauer i wsp., Service Orientation...

42 R. Krupski, Podstawy organizacji i zarzq̨dzania, „Prace Naukowe Wałbrzyskiej Szkoły Zarządzania i Przedsiębiorczości”, seria „Zarządzania i Marketing”, Wydawnictwo Ibis, Wrocław 2004, s. 65. 
organizacjami, w których zachodzi wymiana informacyjna, materialna lub energetyczna $^{43}$. Jak zauważa Czakon ${ }^{44}$, strony wymiany międzyorganizacyjnej (tutaj przedsiębiorstwo produkcyjne oraz klienci końcowi i/lub klienci pośredni) muszą przejawiać wzajemne zaangażowanie. Niniejsze opracowanie ograniczono do przedstawienia wyników badań nad więzami organizacyjnymi.

Chociaż wśród badaczy występuje powszechna zgodność co do pozytywnego wpływu zarówno współpracy między wydziałami ${ }^{45}$, jak i między organizacjami ${ }^{46}$ na osiągane przez przedsiębiorstwa wyniki czy przewagę konkurencyjną, to autorzy jednocześnie starają się definiować warunki konieczne do osiągnięcia takich rezultatów. Podobnie jest wśród autorów badających zjawisko serwicyzacji ${ }^{47}$, którzy do tych czynników zaliczają kryterium wyodrębnienia podstawowych jednostek organizacyjnych czy zorientowanie oferty produktowej na usługi. Fliess i Lexutt ${ }^{48}$ na bazie przeglądu literatury stawiają hipotezę, że niezależnie od tego, czy działalność usługowa jest zintegrowana, czy wydzielona od działalności produktowej, czynnikiem przyczyniającym się do sukcesu serwicyzacji jest wymiana informacji wewnątrz przedsiębiorstwa i między klientami. Jednocześnie autorzy przypuszczają, że efekt będzie większy przy większym stopniu zorientowania oferty produktowej na usługi. W przypadku oferty produktowej charakteryzującej się wysokim stopniem orientacji usługowej producenci są zmuszeni do integracji takich jednostek organizacyjnych ${ }^{49}$. Jednocześnie muszą wspierać współpracę wewnątrz firmy w celu efektywnego i skutecznego spełnienia wymagań klientów. Storbacka ${ }^{50}$ stwierdza, że zintegrowane rozwiązania produktowo-usługowe o wysokim poziomie orientacji usługowej z natury mają charakter międzyfunkcyjny. Antioco i współautorzy ${ }^{51}$ zbadali związek między relacją współpracy wewnątrz firmy a orientacją usługową oferty produktowej. Autorzy, jako nieliczni w swoich badaniach, uwzględnili heterogeniczność usług,

43 W. Czakon, Dynamika więzi międzyorganizacyjnych przedsiębiorstwa, Wydawnictwo Akademii Ekonomicznej, Katowice 2007, s. 9.

44 Tamże.

45 Na przykład A. Zakrzewska-Bielawska, Relacje między strategiq a strukturq organizacyjnq..., s. 7; B. Edvardsson i wsp., The impact of intra- and interfirm collaboration on service innovation in B2B firms, 30. Konferencja IMP, Bordeaux 2014, https://www.impgroup.org/paper_vi ew.php?viewPaper=8187 (dostęp: 11.12.2018).

46 W. Czakon, Dynamika więzi...; B. Edvardsson i wsp., The impact...

47 Na przykład S. Fliess, E. Lexutt, How to be successful with servitization...; H. Gebauer i wsp., Service Orientation...; M. Antioco i wsp., Organizational antecedents...

48 S. Fliess, E. Lexutt, How to be successful with servitization...

49 W.A. Neu, S.W. Brown, Manufacturers forming successful complex business services...

50 K. Storbacka, A solution business model: Capabilities and management practices for integrated solutions, „Industrial Marketing Management” 2011, vol. 40, s. 709.

51 M. Antioco i wsp., Organizational antecedents... 
tj. wyróżnili dwie kategorie oferty produktowo-usługowej. W pierwszej kategorii oferty produktowej (mniej zorientowanej usługowo) dominują usługi zapewniające poprawne funkcjonowanie produktu, a w drugiej (o dużym stopniu zorientowania na usługi) usługi wspierające działania i procesy biznesowe klientów. Wyniki badań pokazały, że nie ma bezpośredniego związku między współpracą międzyfunkcyjną a rodzajami orientacji usługowej oferty produktowej. Jednak autorzy zauważyli, że związek między usługami wspierającymi działania klienta (oferta o wyższym stopniu orientacji usługowej) a osiąganą wielkością sprzedaży produktów staje się silniejszy wraz ze wzrostem współpracy międzyfunkcyjnej.

Podsumowując, można stwierdzić, że badacze nie są zgodni co do tego, czy (a jeśli tak, to w jakich warunkach) integracja lub wydzielenie działalności usługowej od działalności związanej z produktem przyczynia się do sukcesu serwicyzacji producentów. Po drugie, na ogół panuje zgodność, że współpraca międzyfunkcyjna oraz międzyorganizacyjna są ważnymi aspektami integracji usług i produktów w postaci zintegrowanej oferty produktowo-usługowej. Jednak nasza wiedza na temat tego, czy czynniki te są niezbędnymi warunkami na tym samym poziomie przy różnym stopniu zorientowania oferty produktowej na usługi, do tej pory nie została zbadana. Po trzecie, w badaniach nad warunkami koniecznymi sukcesu serwicyzacji, poza nielicznymi przypadkami ${ }^{52}$, brakuje takich, które pozwoliłyby dowieść prawdziwości postawionych hipotez poprzez statystyczne uogólnienie na większej próbie niż kilka zbadanych przypadków. Większość prowadzonych badań na ten temat miała charakter eksploracyjny, jakościowy, na podstawie studiów przypadków ${ }^{53}$.

\section{Metoda badawcza}

\section{Metoda NCA}

W celu poznania warunków koniecznych do osiągnięcia przez przedsiębiorstwa produkcyjne danego poziomu przychodów ze sprzedaży rozwiązań produktowo-usługowych, jakimi mogą być:

- wydzielenie lub integracja komórek organizacyjnych odpowiedzialnych za dostarczanie komponentu produktowego i usługowego oferty produktowej;

- więzi międzyfunkcyjne, wykorzystano metodę $\mathrm{NCA}^{54}$.

52 Tamże.

53 C. Raddats i wsp., Servitization...

54 J. Dul, Necessary condition analysis... 
Metoda należy do grupy metod nieparametrycznych, w których wykorzystuje się procedurę programowania liniowego, natomiast nie uwzględnia się wpływu czynnika losowego na cechy obiektów. Zaletą NCA wynikającą z nieparametryczności metody jest to, że nie wymaga się przedstawienia funkcyjnej zależności między analizowanymi zmiennymi. NCA pomaga badaczom w określeniu niezbędnego poziomu warunku koniecznego (ale niewystarczającego) przy osiągnięciu zamierzonego poziomu efektu (wyniku). Pozwala w takim razie odpowiedzieć na pytanie „Jaki minimalny poziom wartości zmiennej niezależnej $X$ jest konieczny dla danego poziomu wartości zmiennej zależnej Y (rozumianej jako pożądany wynik, efekt, rezultat)?”. W celu identyfikacji niezbędnego poziomu wartości danej zmiennej, aby mógł wystąpić pożądany efekt, w metodzie NCA wyznacza się tzw. linię sufitu, pułapu (ceiling line). W kartezjańskim układzie współrzędnych linia sufitu jest linią graniczną oddzielającą strefę bez zarejestrowanych obserwacji (punktów) od strefy, w której obserwacje te się znajdują. Linia sufitu przybiera postać niemalejącej funkcji (liniowej) z przedziałami ${ }^{55}$. Jest wiele sposobów wyznaczenia takiej linii. W NCA zaadaptowano między innymi rozwiązania z opracowanej wcześniej metody granicznej analizy danych (Data Envelopment Analysis - DEA) oraz metody swobodnego ustalania obwiedni (Free Disposal Hull - FDH) ${ }^{56}$. „Pusta” strefa (zazwyczaj powyżej linii pułapu) jest dowodem istnienia warunku koniecznego. Będzie ona różnej wielkości, określając w ten sposób miarę efektu konieczności $(d)$, ale nie warunku wystarczalności. W NCA wielkość efektu warunku koniecznego wyrażana jest jako wielkość strefy nad linią sufitu („pusta” strefa) do całego obszaru zarejestrowanych obserwacji ${ }^{57}$. Efekt jest silniejszy wraz ze wzrostem strefy nad linią sufitu. Podobnie jak przy innych miarach wielkości efektu, jak na przykład przy współczynniku korelacji $r$, w NCA wartość efektu warunku koniecznego mieści się w zakresie od 0 do $1^{58}$.

\section{Narzędzie pomiarowe}

Konstrukty użyte w badaniu zostały wygenerowane przy użyciu pozycji skal wykorzystanych we wcześniejszych badaniach. W celu pomiaru orientacji usługowej oferty produktowej skorzystano ze wspominanej już klasyfikacji usług według Mathieu ${ }^{59}$, dzieląc tym samym ofertę produktową na taką, w której dominują usługi

\section{Tamże.}

56 J. Dul, Necessary condition analysis...; A. Ćwiąkała-Małys, W. Nowak, Wybrane metody pomiaru efektywności podmiotu gospodarczego, Wydawnictwo Uniwersytetu Wrocławskiego, Wroctaw 2009.

57 J. Dul, Necessary condition analysis...

58 Tamże.

59 V. Mathieu, Product services... 
zapewniające poprawne funkcjonowanie produktu (SSP), oraz taką, w której dominują usługi wspierające działania i procesy biznesowe klientów (SSC). Respondenci wskazali, który rodzaj usług z przedstawionej listy firma ma w swojej ofercie produktowej. Lista usług SSP $(n=11)$ i SSC $(n=8)$ została zaczerpnięta ze wcześniejszych badań ${ }^{60}$. Dla każdej z 19 przedstawionych usług zmienna była dychotomiczna ( 0 = „nie oferujemy”, 1 = „oferujemy”). Ponieważ liczba usług była różna dla każdej z dwóch grup, uzyskane wielkości zostały znormalizowane. W zależności od tego, która znormalizowana wartość - SSP czy SSC - była większa, przyjęto, że producent ma ofertę produktową bardziej zorientowaną odpowiednio na SSP lub SSC. $\mathrm{Na}$ tej podstawie podzielono przedsiębiorstwa na dwie grupy, które były podstawą poszukiwania warunków koniecznych w zależności od rodzaju oferowanych usług. W pierwszej grupie (SSP) znalazło się 112 przedsiębiorstw, w drugiej (SSC) 72.

Na podstawie propozycji przedstawionej przez Antioco i współautorów ${ }^{61}$ osiągane przez przedsiębiorstwa wyniki zostały pozyskane od respondentów poprzez zadeklarowanie przez nich udziału procentowego uzyskiwanych przychodów ze sprzedaży usług w ogólnych przychodach ze sprzedaży. Zastosowano tutaj subiektywną miarę, ponieważ, jak stwierdzają Homburg, Hoyer i Fassnacht ${ }^{62}$, w przypadku zintegrowanej oferty produktowo-usługowej obiektywna miara, wyrażona na przykład kwotowo, jest w wielu przypadkach bardzo trudna (jeśli nie niemożliwa) do pozyskania. Sytuacja taka ma miejsce przede wszystkim, gdy w przedsiębiorstwie nie wydzielono jednostki organizacyjnej z przypisaną pełną odpowiedzialnością za ponoszone koszty i zyski z działalności usługowej63. Diagnozę, czy w przedsiębiorstwie wydzielono autonomiczną jednostkę usługową, identyfikowano poprzez zapytanie respondentów o posiadanie bądź nie wyodrębnionej komórki organizacyjnej z odpowiedzialnością za marketing usług, sprzedaż usług, ich dostawę czy rozwój (zmienna binarna, gdzie $1=$ „tak”, $0=$ „nie”).

Współpraca organizacyjna została zoperacjonalizowana na podstawie Storbackiej ${ }^{64}$ oraz Langeraka, Hultinka i Robbena ${ }^{65}$. Ostatecznie respondenci ocenili

60 A. Eggert, C. Thiesbrummel, C. Deutscher, Heading for new shores: Do service and hybrid innovations outperform product innovations in industrial companies?, „Industrial Marketing Management" 2015, vol. 45, s. 173-183.

61 M. Antioco i wsp., Organizational antecedents...

62 C. Homburg, W.D. Hoyer, M. Fassnacht, Service orientation of a retailer's business strategy: Dimensions, antecedents, and performance outcomes, „Journal of Marketing” 2002, vol. 66, s. 86-101.

63 H. Gebauer i wsp., Service Orientation...

64 K. Storbacka, A solution business model...

65 F. Langerak, J.E. Hultink, H.S. Robben, The role of predevelopment activities in the relationship between market orientation and performance, „R\&D Management” 2004, vol. 34, s. 295-309. 
stwierdzenia odnoszące się do występujących interakcji zespołów pracowników uczestniczących w zadaniach związanych z usługami (rozwój usług, marketing, sprzedaż usług) $\mathrm{z}$ innymi funkcjami w przedsiębiorstwie (rozwój produktu, produkcja, marketing). Skala składała się z następujących pozycji:

1) pracownicy poszczególnych komórek organizacyjnych (działów) koordynują swoje działania związane $\mathrm{z}$ dostarczanymi usługami naszym klientom;

2) poszczególne komórki organizacyjne (działy) wspólnie zaspokajają potrzeby klientów;

3) poszczególne komórki organizacyjne (działy) są współodpowiedzialne za relacje z klientami;

4) pracownicy różnych komórek organizacyjnych (działów) wspólnie uczestniczą w wizytach roboczych u klientów;

5) pracownicy różnych komórek organizacyjnych (działów) wspólnie podejmują decyzje, które wpływają na relacje z klientami.

Oceny dokonano na pięciostopniowej skali Likerta (od 1 - „nie zgadzam się”, przez 3 - „ani się zgadzam, ani nie zgadzam”, do 5 - „całkowicie się zgadzam”). W celu określenia rzetelności skali posłużono się współczynnikiem alfa-Cronbacha, tj. miarą określającą spójność pozycji obecnych w danej skali (innymi słowy stwierdzającą, w jakim stopniu pytania wchodzące w skład danego czynnika określają ten sam konstrukt teoretyczny). Otrzymana wartość współczynnika alfa-Cronbacha na poziomie 0,69 została osiągnięta po usunięciu stwierdzenia nr 5 . Przy wartości odcięcia wynoszącej 0,6 dla pięciopunktowej skali Likerta ${ }^{66}$ ostateczne narzędzie pomiarowe składające się z czterech pozycji ma wystarczającą rzetelność do pomiaru więzi międzyfunkcyjnych.

\section{Próba badawcza i sposób zbierania danych}

Badanymi jednostkami były przedsiębiorstwa produkcyjne mające swoją siedzibę na terytorium Polski, które deklarowały posiadanie usług w swojej w ofercie produktowej, zatrudniające co najmniej dziesięciu pracowników. Próbę do badań dobrano celowo na podstawie danych GUS z rejestru REGON, 2017. Ponadto dobór przedsiębiorstw był kwotowy - starano się zachować zgodność z danymi GUS $\mathrm{w}$ takich wymiarach jak procentowy udział przedsiębiorstw $\mathrm{z}$ danej sekcji i działu PKD oraz według struktury zatrudnienia. Do zebrania danych zastosowano metodę wywiadu bezpośredniego typu CATI (wywiad telefoniczny wspomagany komputerowo). Wywiady przeprowadziła jedna z największych firm w Polsce prowadząca tego typu badania. Ostatecznie próba badawcza składała się z 320

66 J.F. Hair i wsp., Multivariate data analysis, Prentice Hall International, New Jersey 2006. 
przedsiębiorstw. Respondentami byli pracownicy wyższego i średniego szczebla kierowniczego, tj. właściciele, prezesi, dyrektorzy zarządzający, dyrektorzy sprzedaży i marketingu, kierownicy działów usług oraz menedżerowie ds. rozwoju nowych produktów. Respondenci reprezentowali firmy z siedmiu różnych branż: produkcja maszyn i urządzeń (41\%), produkcja sprzętu elektrycznego (16\%), działalność związana z oprogramowaniem i doradztwem w zakresie informatyki oraz działalność powiązana (13\%), produkcja pojazdów samochodowych, przyczep i naczep przyczepy (10\%), produkcja pozostałego sprzętu transportowego (9\%), produkcja komputerów (8\%), działalność telekomunikacyjna (3\%). Badane firmy zatrudniały: 10-49 pracowników (51\%), 50-249 pracowników (41\%), 250 pracowników i więcej (9\%).

\section{Wyniki z analizy NCA}

Badania objęły, po pierwsze, wyznaczenie linii sufitu dla dwóch warunków koniecznych (wydzielenie jednostki usługowej - WJU oraz współpraca międzyfunkcyjna - IntraFirm) w zależności od rodzaju zorientowania na usługi oferty produktowej (SSP i SSC) (rysunek 1). Z dwóch zaimplementowanych metod wyznaczania linii sufitu, tj. CE-FDH i CR-FDH, przy danych dyskretnych lepsze dopasowanie linii uzyskuje się za pomocą pierwszej metody ${ }^{67}$. Po drugie, wyznaczono wielkości efektów warunków koniecznych (tabela 1). Na podstawie doświadczeń przyjmuje się ocenę efektu jako „średni”, gdy wartość mieści się pomiędzy 0,1 a 0,3, powyżej 0,3 do 0,5 jako „duży”, a powyżej 0,5 jako „bardzo duży"68. Po trzecie, wygenerowano tabelę stopnia ograniczenia przez warunki konieczne uzyskiwanych poziomów efektów (UPU) w podziale na rodzaj oferty (SSP i SSC) (tabela 2).

Tabela 1. Wyniki analizy warunków koniecznych: wartości efektów $d$

\begin{tabular}{|l|c|c|}
\hline Wymiar/wartość efektu warunku koniecznego $d_{\text {(Metoda wyznaczenia linii sufitu) }}$ & $d_{\text {(CE_FDH) }}$ & $d_{\text {(CR_FDH) }}$ \\
\hline WJU (SSP) & 0,000 & 0,000 \\
\hline IntraFirm (SSP) & 0,266 & 0,206 \\
\hline WJU (SSC) & 0,000 & 0,000 \\
\hline IntraFirm (SSC) & 0,525 & 0,350 \\
\hline
\end{tabular}

Źródto: opracowanie własne.

67 J. Dul, Necessary condition analysis...

68 Tamże, s. 271. 
Tabela 2. Tabela ograniczeń: wymagane minimalne poziomy warunku koniecznego dla różnych pożądanych poziomów osiąganych wyników (w podziale na rodzaj oferty usługowej)

\begin{tabular}{|l|c|c|c|c|c|c|c|c|c|c|c|}
\hline \multicolumn{1}{|c|}{ UPU \% } & 0 & 10 & 20 & 30 & 40 & 50 & 60 & 70 & 80 & 90 & 100 \\
\hline $\begin{array}{l}\text { IntraFirm } \\
\text { (SSP) }\end{array}$ & NN & NN & NN & 2,20 & 9,90 & 17,70 & 25,50 & 33,30 & 41,00 & 48,80 & 56,60 \\
\hline $\begin{array}{l}\text { IntraFirm } \\
\text { (SSC) }\end{array}$ & 5,00 & 11,00 & 17,00 & 23,00 & 29,00 & 35,00 & 41,00 & 47,00 & 53,00 & 59,00 & 65,00 \\
\hline
\end{tabular}

NN - wystąpienie warunku nie jest konieczne.

Źródło: opracowanie własne.
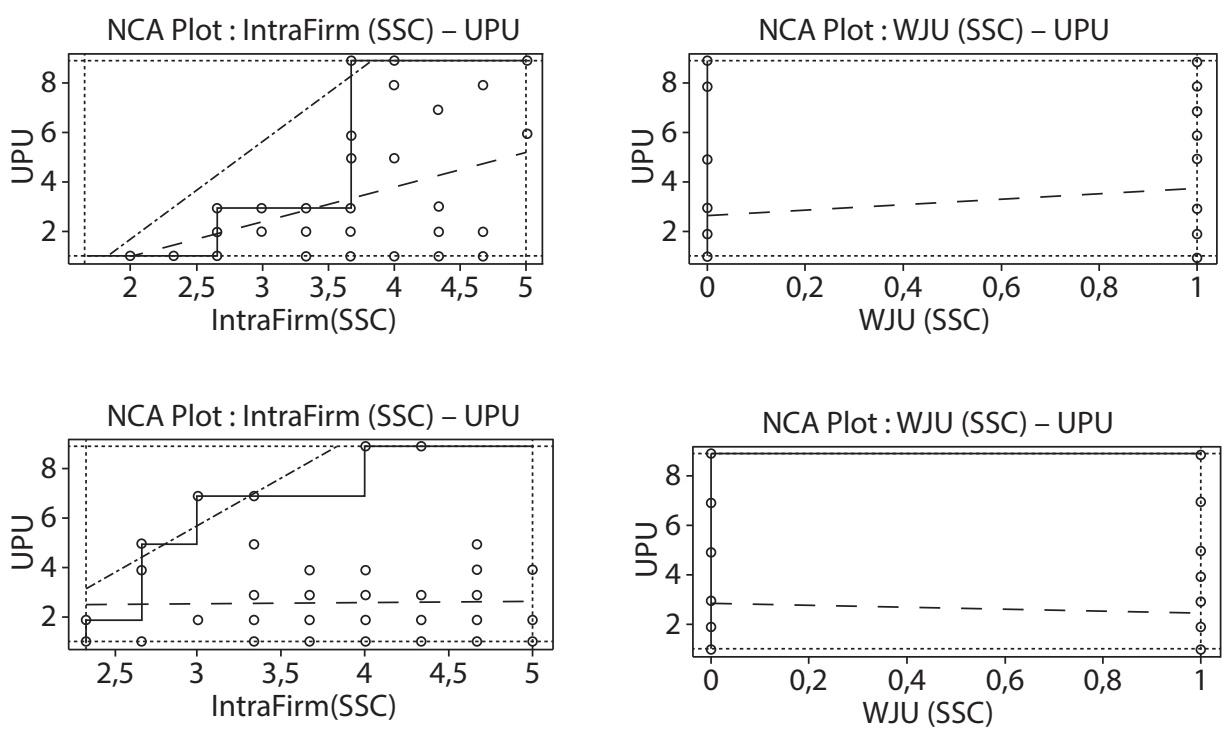

$$
\begin{aligned}
& -- \text { OLS } \\
& - \text { CE-FDH } \\
& -\cdots \text { CR-FDH }
\end{aligned}
$$

Rysunek 1. Linie sufitu (pułapu) dla dwóch warunków koniecznych (wydzielenie jednostki usługowej - WJU, współpraca międzyfunkcyjna - IntraFirm) w zależności od rodzaju zorientowania na usługi oferty produktowej (SSP i SSC)

Źródto: opracowanie własne.

Otrzymane wyniki efektów konieczności (d) (tabela 1) metodą CE-FDH (jak wyżej wspomniano, dającą lepsze dopasowanie przy zmiennych dyskretnych), wskazują, że zarówno w przypadku oferty produktowej, w której dominują usługi typu SSP, jak i w przypadku SSC wartości warunku koniecznego wydzielenia autonomicznej jednostki organizacyjnej odpowiedzialnej za usługi (WJU SSP i WJU SSC) są równe zero $\left(d_{\left(\mathrm{CE} \_\mathrm{FDH}\right)}=0\right)$. Oznacza to, że kryterium wydzielenia jednostki usługowej nie jest warunkiem koniecznym wzrostu udziału przychodów ze sprzedaży usług. Inaczej wyniki 
kształtują się przy drugim warunku, tj. współpracy międzyfunkcyjnej (IntraFirm) pomiędzy funkcjami produktowymi i usługowymi. W tym przypadku wartość $d_{\left(\mathrm{CE} \_F D H\right)}$ jest mniejsza dla IntraFirm (SSP), gdzie $d_{\left(\mathrm{CE} \_\mathrm{FDH}\right)}=0,266$ (średni efekt według przyjętej skali), niż w przypadku IntraFirm (SSC), gdzie $d_{\left(\mathrm{CE} \_\mathrm{FDH}\right)}=0,525$ (bardzo duży efekt). Oznacza to, że więzi międzyfunkcyjne pomiędzy zadaniami związanymi z produktami i usługami są warunkiem koniecznym przy osiąganiu określonych przychodów ze sprzedaży usług - zarówno przy ofercie usług skierowanej na poprawne funkcjonowanie produktu (SSP), jak i na procesy biznesowe i operacyjne klienta (SSC). Jednak wartość efektu $(d)$ jest silniejsza w przypadku usług z grupy SCC. Oznacza to, że więzi organizacyjne silniej ograniczają przychody ze sprzedaży usług kategorii SSC. Dodatkową wiedzę wnosi tabela ograniczeń (tabela 2), budowana na podstawie wyznaczonej linii sufitu ${ }^{69}$. Wartości zmiennej zależnej (tutaj udział przychodów sprzedaży UPU) są wyrażone jako procent zakresu (obserwowanych) wartości $(0 \%$ = najniższa zaobserwowana wartość, 100\% - najwyższa zaobserwowana). Najniższą obserwowaną wartością UPU było „do 10\% udziału przychodów ze sprzedaży usług w całkowitych przychodach ze sprzedaży”. Najwyższą obserwowaną wartością było osiągnięcie „powyżej 80\%” przychodów ze sprzedaży usług. Pozostałe wiersze odpowiadają wartości zmiennych niezależnych zgodnie z linią sufitu (również wyrażone jako procent zakresu). Na tej podstawie wyniki z tabeli 2 wskazują, że w przypadku oferty produktowej zorientowanej na SSC koniecznym warunkiem osiągnięcia „do 10\%” przychodów ze sprzedaży usług jest posiadanie więzi między funkcjami produktowymi i usługowymi na poziomie 5\% (oczywiście przyjętej w badaniach skali). W przypadku oferty produktowej z dominacją usług typu SSP, więzi międzyfunkcyjne stają się warunkiem koniecznym, jeśli chce się osiągnąć poziom przychodów z usług wyższy niż 20\%.

\section{Podsumowanie}

Celem przeprowadzonych badań była identyfikacja warunków koniecznych do osiągania przychodów ze sprzedaży usług przez przedsiębiorstwa produkcyjne wkraczające na drogę serwicyzacji. Badaniom poddano dwa warunki - wydzielenie usługowej jednostki organizacyjnej oraz współpracę międzyfunkcyjną przy różnych rodzajach przyjętej orientacji oferty produktowej na usługi. Do identyfikacji warunków koniecznych wykorzystano metodę Necessary Condition Analysis (NCA).

Otrzymane wyniki badań pokazały, że osiągane przychody ze sprzedaży usług nie są warunkowane kryterium strukturyzacji wewnętrznej organizacji. W badanej próbie zarówno przedsiębiorstwa, które wyodrębniły komórki organizacyjne na podstawie podobieństwa czynności i zadań (komórki odpowiedzialne

69 J. Dul, Necessary condition analysis... 
za produkt i za usługi), jak i przy kryterium obiektowym, gdzie podstawą strukturyzacji jest podobieństwo specyficznego przedmiotu działalności (integracja działań produktowych i usługowych), osiągały dobre i złe wyniki ze sprzedaży usług. (tabela 1) Oznacza to, że nie ma optymalnego projektu organizacji dla producentów podążających różnymi trajektoriami serwicyzacji. Producenci muszą dostosować projekt do przyjętej strategii usługowej, a ta - w miarę szybkiego rozwoju nowych technologii (w tym tych, które składają się na Przemysł 4.0) - zmienia się wraz ze wzrostem „dojrzałości” serwicyzacji producentów.

Drugi wniosek, który można wyciągnąć z przeprowadzonych badań, dotyczy roli więzi organizacyjnych $w$ rozwoju i dostarczaniu usług towarzyszących sprzedawanym produktom (SSP) oraz procesom biznesowym i operacyjnym klienta (SSC). Więzi organizacyjne są warunkiem koniecznym do osiągania przychodów ze sprzedaży, zarówno w jednej, jak i drugiej kategorii usług. Tabela ograniczeń (tabela 2) dodatkowo pokazała, że więzi międzyfunkcyjne silniej ograniczają przychody ze sprzedaży usług w przypadku, gdy w przedsiębiorstwie dominują usługi SSC. Oznacza to, że przedsiębiorstwa, które poszerzają swoją ofertę o bardziej złożone usługi (za takie uważa się usługi SSC), chcąc osiągać większe przychody ze sprzedaży usług, powinny przywiązywać szczególną uwagę do rozwoju więzi organizacyjnych. Usługi SSC są nakierowane na procesy klienta, a współpraca międzyfunkcyjna pozwala na bardziej „holistyczne” podejście do zaspokajania jego potrzeb. To „holistyczne" podejście polega na międzyfunkcyjnym zaangażowaniu w poszczególne działania, które obejmują finanse, produkcję, dostawy, rozwój spersonalizowanych rozwiązań produktowo-usługowych i obsługę klienta.

Niniejsze badania, podobnie jak inne, mają swoje ograniczenia. Metoda NCA, którą wykorzystano, jest stosunkowo nowa i - pomimo coraz szerszego jej stosowania - jako narzędzie badawcze jest wciąż rozwijana. Ponadto jest raczej metodą uzupełniającą, a nie konkurencyjną w stosunku do tradycyjnych metod ilościowych. Dlatego zebrane dane w kolejnych etapach badań zostaną przeanalizowane także bardziej ugruntowanymi w nauce metodami statystycznymi w celu porównania osiągniętych wyników. Pozwoli to także, oprócz potwierdzenia/zanegowania uzyskanych tutaj wyników, na kolejną weryfikację rzetelności metody NCA.

W badaniach jako miarę efektu serwicyzacji przyjęto przychody ze sprzedaży, subiektywnie wskazywane przez respondentów. W kolejnych badaniach proponuje się przyjąć bardziej obiektywne miary oraz inne wymiary efektów serwicyzacji, na przykład osiąganą przewagę konkurencyjną.

Edvardsson i współautorzy ${ }^{70}$ wskazują, że współpraca międzyorganizacyjna może wpłynąć pozytywnie na wewnętrzną koordynację działań rozwoju

70 B. Edvardsson i wsp., The impact... 
i dostarczania rozwiązań produktowo-usługowych. Dlatego w przyszłości interesujące byłoby także zbadanie koniecznego poziomu więzi organizacyjnych przy osiąganiu określonych wyników przez przedsiębiorstwa produkcyjne w podziale na rodzaj dostarczanych rozwiązań produktowo-usługowych.

\section{Bibliografia}

Alghisi A., Saccani N., Internal and external alignment in the Servitization journey - Overcoming the challenges, „Production Planning and Control” 2015, vol. 26, s. 1219-1232.

Antioco M., Moenaert R.K., Lindgreen A., Wetzels M.G., Organizational antecedents to and consequences of service business orientations in manufacturing companies, „Journal of the Academy of Marketing Science" 2008, vol. 36, s. 337-358.

Auguste B.G., Harmon E.P., Pandit V., The right service strategies for product companies, „McKinsey Quarterly" 2006, vol. 1, s. 40-51.

Böhm E., Eggert A., Thiesbrummel C., Service transition: A viable option for manufacturing companies with deteriorating financial performance, „Industrial Marketing Management” 2017, vol. 60, s. 101-111.

Coreynen W., Matthyssens P., Van Bockhaven W., Boosting servitization through digitization: pathways and dynamic resource configurations for manufacturers, „Industrial Marketing Management" 2017, vol. 60, s. 42-53.

Czakon W., Dynamika więzi międzyorganizacyjnych przedsiębiorstwa, Wydawnictwo Akademii Ekonomicznej, Katowice 2007.

Ćwiąkała-Małys A., Nowak W., Wybrane metody pomiaru efektywności podmiotu gospodarczego, Wydawnictwo Uniwersytetu Wroctawskiego, Wroctaw 2009.

Dul J., Necessary condition analysis (NCA) logic and methodology of „Necessary but Not Sufficient" causality, „Organizational Research Methods” 2016, vol. 19, s. 10-52.

Edvardsson B., Jaakkola E., Sebastiani R., Witell L., The impact of intra- and interfirm collaboration on service innovation in B2B firms, 30. Konferencja IMP, Bordeaux 2014, https://www .impgroup.org/paper_view.php?viewPaper=8187 (dostęp: 11.12.2018).

Eggert A., Thiesbrummel C., Deutscher C., Heading for new shores: Do service and hybrid innovations outperform product innovations in industrial companies?, „Industrial Marketing Management" 2015, vol. 45, s. 173-183.

Fliess S., Lexutt E., How to be successful with servitization - Guidelines for research and management, „Industrial Marketing Management” 2019, vol. 78, s. 58-75.

Frank A.G., Dalenogare L.S., Ayala N.F., Industry 4.0 technologies: implementation patterns in manufacturing companies, „International Journal of Production Economics” 2019, vol. 210, s. $15-26$.

Gebauer H., Identifying service strategies in product manufacturing companies by exploring environment - strategy configurations, „Industrial Marketing Management” 2008, vol. 37, s. $278-291$.

Gebauer H., Pütz F., Fischer T., Fleisch E., Service Orientation of Organizational Structures, „, Journal of Relationship Marketing" 2009, vol. 8: 2, s. 103-126.

Gersch M., Goeke C., Industry transformation - conceptual considerations from an evolutionary perspective, „Journal of Business Market Management” 2007, vol. 1, s. 151-182. 
Gremyr I., Witell L., Löfberg N., Edvardsson B., Fundin A., Understanding new service development and service innovation through innovation modes, „Journal of Business and Industrial Marketing" 2014, vol. 29, s. 123-131.

Hair J.F., Black W.C., Babin B.J., Anderson R.E., Tatham R.L., Multivariate data analysis, Prentice Hall International, New Jersey 2006.

Homburg C., Hoyer W.D., Fassnacht M., Service orientation of a retailer's business strategy: Dimensions, antecedents, and performance outcomes, „Journal of Marketing” 2002, vol. 66, s. 86-101.

Kowalkowski C., Gebauer H., Oliva R., Service growth in product firms: past, present, and future, „Industrial Marketing Management” 2017, vol. 60, s. 82-88.

Krupski R., Podstawy organizacji i zarządzania, wyd. 5, „Prace Naukowe Wałbrzyskiej Szkoły Zarządzania i Przedsiębiorczości”, seria „Zarządzania i Marketing”, Wydawnictwo Ibis, Wrocław 2004.

Langerak F., Hultink J.E., Robben H.S., The role of predevelopment activities in the relationship between market orientation and performance, „R\&D Management” 2004, vol. 34, s. 295-309.

Lichniak I., Ku gospodarce usług, [w:] L. Lichniak (red.), Serwicyzacja polskiej gospodarki, Oficyna Wydawnicza SGH - Szkoła Główna Handlowa w Warszawie, Warszawa 2010, s. 11-24.

Martinez V., Neely A., Velu C., Leinster-Evans S., Bisessar D., Exploring the journey to services, „International Journal of Production Economics" 2017, vol. 192, s. 66-80.

Mathieu V., Product services: from a service supporting the product to a service supporting the client, „Journal of Business and Industrial Marketing” 2001, vol. 16, s. 39-58.

Matusek M., Innowacje usług w przedsiębiorstwach produkcyjnych - jak uniknqć „paradoksu usług”, „Organizacja i Kierowanie” 2016, nr 2, s. 87-103.

Mintzberg H., Structure in fives: Designing effective organizations, Prentice-Hall, Inc., Englewood Cliffs 1993.

Neu W.A., Forming successful business-to-business services in goods-dominant firms, „Journal of Service Research" 2005, vol. 8, s. 3-17.

Neu W.A., Brown S.W., Manufacturers forming successful complex business services: Designing an organization to fit the market, „International Journal of Service Industry Management” 2008, vol. 19, s. 232-251.

Oliva R., Gebauer H., Brann J.M., Separate or integrate? Assessing the impact of separation between product and service business on service performance in product manufacturing firms, „Journal of Business-to-Business Marketing” 2012, vol. 19, s. 309-334.

Raddats C., Kowalkowski C., Benedettini O., Burton J., Gebauer H., Servitization: A contemporary thematic review of four major research streams, „Industrial Marketing Management” 2019, vol. 83, s. 207-223.

Raja Jawwad Z., Chakkol M., Johnson M., Beltagui A., Organizing for servitization: examining frontand back-end design configurations, „International Journal of Operations \& Production Management" 2018, vol. 38, issue 1, s. 249-271.

Reischauer G., Industry 4.0 as policy-driven discourse to institutionalize innovation systems in manufacturing, „Technological Forecasting and Social Change” 2018, vol. 132, s. 26-33.

Storbacka K., A solution business model: Capabilities and management practices for integrated solutions, „Industrial Marketing Management” 2011, vol. 40, s. 699-711.

Teece D.J., Business models, business strategy and innovation, „Long Range Planning” 2010, vol. 43(2), s. 172-194.

Zakrzewska-Bielawska A., Determinanty struktury organizacyjnej na przykładzie dużych polskich przedsiębiorstw produkcyjnych, [w:] J. Skalik (red.), Zmiana warunkiem sukcesu. Przeobrażenia systemów zarzq̨dzania przedsiębiorstw, „Prace Naukowe Akademii Ekonomicznej 
we Wrocławiu", Wydawnictwo Akademii Ekonomicznej we Wroctawiu, Wroctaw 2007, s. $102-103$.

Zakrzewska-Bielawska A., Relacje między strategiq a strukturq organizacyjnq w przedsiębiorstwach sektora wysokich technologii, „Zeszyty Naukowe Politechniki Łódzkiej” 2011, nr 1095.

Żabiński L., Marketing produktów systemowych, Polskie Wydawnictwo Ekonomiczne, Warszawa 2012.

\section{Streszczenie}

Celem opracowania jest zbadanie poziomu konieczności wystąpienia dwóch warunków, tj. wydzielenia usługowej jednostki organizacyjnej oraz współpracy międzyfunkcyjnej, do osiągnięcia różnych poziomów przychodów ze sprzedaży usług przedsiębiorstw produkcyjnych w zależności od rodzaju przyjętej orientacji oferty produktowej na usługi (tj. usługi wspierające produkt - SSP i usługi wspierające działania klienta - SSC). Serwicyzacja staje się obecnie ważnym czynnikiem sprzyjającym konkurencyjności producentów. Zjawisko to, rozumiane jako przyjęcie strategii biznesowej zorientowanej na usługi, zgodnie z teorią dopasowania organizacyjnego wymaga m.in. zmian w strukturze organizacyjnej. Producenci mogą wydzielić autonomiczną jednostkę usługową lub dążyć do integracji organizacji usługowej z produktową. W wynikach badań empirycznych oraz w teorii można znaleźć argumenty przemawiające za jedną lub drugą opcją. Niestety, obecnie osiągnięte wyniki wykazują sprzeczność. Na podstawie przeprowadzonych badań ankietowych na próbie 186 producentów warunki konieczne zostały zbadane z wykorzystaniem jednej z nieparametrycznych metod, tj. Necessary Condition Analysis (NCA). Badanie wykazało, że zarówno w przypadku oferty usługowej typu SSP, jak i SSC wydzielenie organizacji usług nie jest warunkiem koniecznym do osiągnięcia zarówno niskiego, jak i wysokiego poziomu przychodów z usług. Tymczasem już współpraca międzyfunkcyjna warunkuje osiąganie różnych poziomów przychodów z usług. Warunek ten silniej ogranicza osiągane przychody z usług w przypadku dostarczania przez producenta oferty kategorii SSC.

Słowa kluczowe: serwicyzacja, orientacja usługowa, Przemysł 4.0, więzi organizacyjne, Necessary Condition Analysis (NCA), analiza warunków koniecznych

\section{Identification of the necessary conditions for the success of manufacturers servitization}

\section{Abstract}

The purpose of this paper is to employ a necessary condition analysis (NCA) approach to investigate the level of necessity of two conditions, separate organization for services and interfirm collaboration for service business performance depending on the type of adopted service orientation (services in support of the product (SSP) and services in support of the client's actions business orientation (SSC). Servitization is now becoming an important factor favorable to manufacturers competitiveness. The adoption of service orientation and adequate service strategies includes building up an ability to deliver services and also, according to contingency theory, it requires changes 
in structure of organization. Unfortunately, it is not clear whether manufacturers should create a separate organization for services or if they should pursue an integration of the service organization into its corresponding product base strategic business unit. Empirical evidence and theoretical contributions can be found to support both sides of the argument. Moreover, some of the findings are inconsistent and even contrary to each other. Using a survey data set collected from a sample of 186 Polish manufacturers, this study explored the levels of necessity of the components by NCA. The research revealed that neither in case of SSP BO nor SSC BO separation of organization for services is not necessary condition to achieve both low and high level of service business performance. Also, the results show that different levels of service business performance require different threshold levels of inter-collaboration. This condition is more necessary when firms are SSC oriented.

Keywords: servitization, service orientation, Industry 4.0, intrafirm collaboration, Necessary Condition Analysis (NCA) 